\title{
Öğrencilerin Güçlü Yönlerinin/Karakter Güçlerinin Keșfedilmesine Yönelik Sınıf İçi Uygulama Önerileri
}

\author{
In-Class Practice Suggestions for Discovering Students' Strengths/Character Strengths
}

\section{Ramazan DEMİR ${ }^{[1]}$ Mehmet MURAT ${ }^{2]}$}

Pozitif psikolojinin önemli çalışma konularından birisi bireyin güçlü yönleridir. Bu çalışmada, güçlü yönlerin/karakter güçlerinin sınıfta keşfedilmesi ve işlevsel olarak kullanılması üzerinde durulmaktadır. Öncelikle, güçlü yönlerin önemi vurgulanmaktadır. Sonra, güçlü yönlerin alanyazında sık karşılaşılan sınıflaması olarak 6 erdem ve 24 karakter gücü kısaca açıklanmaktadır. Devamında, güçlü yönlerin okullar için önemi ve okul uygulamalarına kısaca değinilmektedir. Takip eden bölümde, güçlü yönlere yönelik sınıf uygulamalarının her biri açıklanmıştır. Bu uygulamalar, Güçlü Yönler Sınıfı, Güçlü Yönler Şahsiyetleri, Güçlü Yönler Senaryoları, Güçlü Yönler Kariyer Listesi, Güçlü Yönler Kartı, Güçlü Yönler Takvimi, Güçlü Yönler Ağacı, Güçlü Yönler Filmleri, Güçlü Yönler Kitaplığı, Güçlü Yönler Metaforu, Güçlü Yönler Sessiz Sineması, Güçlü Yönler Jengası, Güçlü Yönler Yapbozu, Güçlü Yönler Bulmacası, Güçlü Yönler Küpü, Güçlü Yönler İsim-Şehiri, Güçlü Yönlerimi Kullanıyorum, Problemlere Karşı Güçlü Yönlerim, Güçlü Yönler Listem, Güçlü Yönler Günlüğüm, Güçlü Yönler Aktivitelerim, Arkadaşlarımın Gözünden Güçlü Yönlerim, Ailemin Gözünden Güçlü Yönlerimdir. Son olarak çalışma sonuç ve öneriler kısmı ile tamamlanmıştır.

Anahtar Kelimeler: pozitif psikoloji, pozitif ĕgitim, pozitif psikoloji uygulamaları, güçlü yönler, karakter güçleri

One of the important study topics of positive psychology is the strengths of the individual. This study focuses on discovering and functionally using strengths/character strengths in the classroom. First, the importance of strengths is emphasized. Then, 6 virtues and 24 character strengths are briefly explained as a common classification of strengths in the literature. In the following, the importance of strengths for schools and school practices are briefly mentioned. The following part explained each of the classroom practices for strengths. These practices are Strengths Class, Strengths Personas, Strengths Scenarios, Strengths Career List, Strengths Card, Strengths Calendar, Strengths Tree, Strengths Movies, Strengths Library, Strengths Metaphor, Strengths Charades, Strengths Jenga, Strengths Jigsaw, Strengths Puzzle, Strengths Cube, Strengths Name-City, I Use My Strengths, My Strengths Against Problems, My Strengths List, My Strengths Diary, My Strengths Activities, My Strengths in The Eyes of My Friends, My Strengths in The Eyes of My Family. Finally, the study was completed with the conclusion and suggestions part.

Keywords: positive psychology, positive education, positive psychology practices, strengths, character strengths önerileri. Humanistic Perspective, 3 (3), 737-752. https://doi.org/10.47793/hp.957527 


\section{GíRiş}

$\mathrm{P}$ sikoloji tarihi incelendiğinde, psikolojinin bireyin veya grupların sıkıntılarını gidermeyi veya azaltmayı hedeflediği görülmektedir. Bununla birlikte, bireyin veya grupların olumlu yönlerine odaklanan yaklaşımlar da mevcuttur. Ancak psikoloji uzunca bir süre büyük oranda eksiklik, problem ve belirtiler ile ilgilenmiştir. Bu duruma en köklü eleştirilerden birisi pozitif psikoloji akımı ile gelmiştir. Pozitif psikoloji, kendinden önceki olumlu bakış içerisinde olan yaklaşımlardan da güç alarak bireyin ve grupların eksikliği, zayıflığı kadar güçlü yönlerinin de olduğunu dile getirmiştir. Bu kapsamda, pozitif psikolojinin birçok çalışma konusu içerisinden bireyin güçlü yönlerine/karakter güçlerine odaklanmak ve bireyin güçlü taraflarını keşfedip geliştirmesini sağlamak önemli bir çalışma alanı olmuştur (Demir ve Türk, 2020; Hefferon ve Boniwell, 2014).

Pozitif psikoloji açısından güçlü yönleri incelemenin ne denli önemli ve merkezi bir konumda yer aldığını yaklaşımın kurucusu Seligman (2002) şu şekilde dile getirmektedir: "Pozitif psikoloji hareketinin mesajı, bizim alanımızın deforme olduğunu hatırlatmaktır. Psikoloji sadece hastalığın, zayıflığın ve zararın incelenmesi değildir; ayrıca güçlü yanların ve iyi özelliklerin de incelenmesidir. Tedavi sadece yanlış olanı onarmak değil; ayrıca doğru olanın inşasıdır." Bu sözlerde de açıkça görüldüğü gibi psikolojinin artık yanlışları gidermekle yetinmemesi gerektiği doğrunun inşası ile de ilgilenmesi gerektiği belirtilmektedir. Pozitif psikoloji yaklaşımın temel bakış açısı bu doğrultudadır. Bahsedilen doğrunun inşasını sağlayacak en önemli yollardan birisi olarak da bireyin veya grupların güçlü yönlerini görmektedir. Çünkü pozitif psikoloji anlayışına göre her birey, olumlu özellikler açısından bir potansiyele sahiptir (Park ve Peterson, 2004). Önemli olan bu potansiyeli açığa çıkabilmektir. Böylelikle, birey ve gruplar karşılaştıkları zor durumlara karşı güçlü yönlerinden faydalanarak bu zorluklarla mücadele edebilecek; mutlu, iyimser ve anlamlı bir yaşam sürdürebilecektir (Demir ve Türk, 2020). Karakter güçlerinin farkına varmak ve bunu kullanabilmek kişiyi ruhsal bozukluklara karşı korumaktadır (Boniwell, 2012). Hatta, karakter güçlerinin gelecek toplum yapısında zekâdan daha ayırıcı bir özellik olarak yer alacağı öngörülmektedir (Hokanson ve Karlson, 2013).

Alanyazın incelendiğinde, güçlü yönleri ele alan birçok yaklaşım olmasına rağmen çalışmaların daha çok yapıldığı sınıflama olarak erdemler ve karakter güçleri göze çarpmaktadır. Bu sınıflama, bozuklukları temel alan Zihinsel Bozuklukların Tanısal ve İstatistiksel El Kitabı (DSM) ve Hastalıkların Uluslararası Sınıflandırması (ICD) bakışlarını eleştirerek güçlü yönleri temel alan bir sisteme dayanmaktadır. Birçok bilim insanının yer aldığı, farklı kültürler ve öğretilerin incelendiği, oldukça kapsamlı bir çalışmanın ürünü olan bu sınıflama sistemi 6 erdem ve 24 karakter gücüne dayanmaktadır. Bu erdemler ve altında yer alan karakter güçleri kısaca şu 
şekilde açıklanabilir. İnsaniyet erdemi, yakınlığa geçmeyi içeren kişilerarası güçleri bünyesinde barındırmaktadır. İnsaniyet erdemi altında yer alan karakter güçleri; sevme, sosyal zekâ ve iyi yüreklilik olarak adlandırılabilir. Aşkınlık erdemi, anlam ve varoluş ile ilgili güçler olarak ifade edilebilir. Aşkınlık erdemi altındaki karakter güçleri; maneviyat, minnettarlık, umut, estetik ve mükemmelliğin takdir edilmesi, mizah olarak adlandırılabilir. Bilgelik erdemi, bilgiye ulaşma ve kullanmayı içeren bilişsel güçler olarak ifade edilebilir. Bilgelik erdemi altındaki karakter güçleri; özgünlük, merak, açık fikirlilik ve çok yönlü bakış olarak adlandırılabilir. Cesaret erdemi, engellere rağmen idareli davranışı içeren duygusal güçler olarak ifade edilebilir. Cesaret erdemi altındaki karakter güçleri; yaşam çoşkusu, dürüstlük, cesur olma ve sebatkârlık olarak adlandırılabilir. Ölçülülük erdemi, aşırıya kaçmamayı içeren güçler olarak ifade dilebilir. Ölçülülük erdemi altındaki karakter güçleri; tedbirlilik, affetme, alçakgönüllülük, öz düzenleme olarak adlandırılabilir. Adalet erdemi, sağlıklı toplumsal yaşam için gerekli yurttaşlıkla ilgili güçler olarak ifade edilebilir. Adalet erdemi altında yer alan karakter güçleri; hakkaniyet, liderlik ve takım çalışması olarak adlandırılabilir (Peterson ve Seligman, 2004). Bunun yanında güçlü yönlere ilişkin diğer sınıflamalar olarak Liston (2014)'un sınıflaması, güç bulucu (Buckingham ve Clifton, 2001; Rath, 2007), erdem projesi (Popov, 2000) yer alabilmektedir. Bu yaklaşımların hepsinin ortak özelliği de bireyde güçlü yönlerin bulunduğunu ifade etmesidir. Ancak her bir yaklaşım bu güçlü yönleri farklı olarak ele almıştır.

Pozitif psikoloji yaklaşımı ile ilgili günümüzde birçok alanda çalışmalar yapılmaktadır. $\mathrm{Bu}$ alanlardan bir tanesi de eğitimdir. Eğitim kurumlarında pozitif psikoloji yaklaşımı ve kavramları çalışılmakta ve bu kurumların daha iyi hale gelmesi hedeflenmektedir. Pozitif psikoloji açısından bu kadar önemli görülen güçlü yönlerin de okul ve sınıf ortamlarında incelenmesi eğitim kurumları ve içerisindeki bireyler açısından büyük faydalar getirebilir. Okulda öğrencilerle sürekli etkileşim içerisinde olan özellikle öğretmen ve psikolojik danışmanlar, öğrencilerin güçlü yönlerini keşfetmesine ve işlevsel olarak kullanmasına destek olarak okulun daha olumlu bir atmosfere kavuşmasına, öğrencilerin istendik davranışlarının artmasına, istenmedik davranışlarının azalmasına katkı sunabilir (Demir ve Murat, 2021). Okulda bulunan ruh sağlığı uzmanları, öğrencilere karakter güçlerini tanıma ve geliştirme aşamasında yardımcı olduğu taktirde; onların akademik gelişimine, özyeterliğine ve mutluluğuna katkı sunarak okul iklimini olumlu kılabilir (Molony ve Henwood, 2010). Milli Eğitim Bakanlığı Sınıf Rehberlik Programı (2020) incelendiğinde, pozitif psikolojiden yararlanabileceği ifade edilerek programda karakter güçlerine yer verildiği görülmektedir. $\mathrm{Bu}$ bağlamda, Seligman ve Peterson (2004) sınıflamasındaki erdemler ve karakter güçleri olarak ifade edilen 6 erdem ve 24 karakter gücünden bahsedilmektedir. Bu açıdan Milli Eğitim Bakanlığı'nın da öğrencilere sunulacak sınıf rehberlik uygulamalarında öğrencilerin güçlü yönlerinin keşfedilmesine ve geliştirilmesine verdiği önem gözükmektedir. 
Psikolojik danışma ve rehberlik hizmetlerinin amaçlarından bir tanesi bireyin kendini gerçekleştirmesidir. Bu amaç, bireyin gizil güçlerinin farkında olması ve bunları kullanabilmesi veya kendi potansiyelinin farkına varıp tam olarak potansiyelini kullanabilmesi olarak ifade edilmektedir (Yeşilyaprak, 2010). Bahsedilen kavramların aslında, bireyin güçlü yönlerinin farkına varması ve bunları kullanabilmesi ile ne kadar benzeşik olduğu görülmektedir. Psikolojik danışma ve rehberlik hizmetlerinin problemi merkeze alan klinik yaklaşımlardan bireyin gizil güçlerini veya güçlü yönlerini ortaya çıkaramayı hedefleyen pozitif yaklaşımlara doğru ilerlediği belirtilmektedir (Eryılmaz, 2013). Bu açıklamalar, psikolojik danışma ve rehberlik hizmetlerinde güçlü yönlerin aslında ne kadar önemli bir yerde durduğunu göstermektedir.

Demir ve Murat (2021), okul ortamında güçlü yönlerin keşfedilmesi ve desteklenmesine yönelik olarak okul geneli yapılabilecek çalışmalar önermektedir. Bu uygulamalar, Güçlü Yönler Gazetesi ve Dergisi, Güçlü Yönler Kulüpleri, Güçlü Yönler Yarışmaları, Güçlü Yönler Belgesi, Güçlü Yönler Kutusu, Güçlü Yönler Sergisi, Güçlü Yönler Köşesi olarak ifade edilmektedir. Yazarlar, söz konusu okul geneli uygulamaları yaparken uygulayıcıların öğrencilerin gelişim dönemi özellikleri, okulun ve öğrencilerin ihtiyaçları, okulun imkânları, okuldaki paydaşların desteğinin alınması vb. özellikleri dikkate alması gerektiklerini; uygulamaların bu kriterlere göre uyarlanabileceğini ve yenilerinin geliştirilebileceğini ifade etmişlerdir. Bu çalışmada da yukarıdaki yazarların önerdiği okul geneli uygulamalardan farklı olarak sınıf içi güçlü yönlerin keşfedilmesi ve işlevsel olarak kullanılmasına katkı sağlayabileceği düşünülen etkinlik önerileri sunulmuştur.

İlgili etkinliklerin psikolojik danışmanlar ve öğretmenler tarafından öğrencilere sınıf ortamında grup çalışmaları şeklinde uygulanması sonucunda, öğrencilerin güçlü yönlerini keşfedip bunları okul ve günlük yaşamlarında işlevsel olarak kullanabileceği düşünülmektedir. Ayrıca bu uygulamaların, psikolojik danışmanlık ve rehberlik hizmetlerinin bazı ilkelerinin de okul ikliminde benimsenmesine katkı sağlayacağı düşünülmektedir. Şöyle ki, psikolojik danışmanlık ve rehberlik hizmetlerinin ilkelerinden birisi, okuldaki her öğrencinin bu hizmetlerden faydalanması olarak belirtilmektedir. Okullarda yaşanan en büyük sorunlardan birisi de bu hizmetlerden sadece problemli öğrencilerin faydalandığı, bu servisi başvuran öğrencilerin problemli olarak görüldügü şeklindedir (Yeşilyaprak, 2010). Bunun sonucunda da öğrenciler, psikolojik danışma ve rehberlik servisine ön yargılı yaklaşabilmekte, etiketleme korkusu yaşayabilmekte, servisten yararlanmakta çekimser kalabilmektedir. $\mathrm{Bu}$ durum da hizmetlerden daha çok öğrencinin faydalanmasını engelleyebilmektedir (Demir ve Türk, 2020). $\mathrm{Bu}$ çalışmada sunulan güçlü yönler uygulamaları ile her öğrencinin rahatlıkla bu hizmetlerden faydalanabildiğini, bu hizmetlerin sadece sorunlarla değil pozitif yönlerle de ilgili olduğunu benimsemesinde katkı sunacağı düşünülmektedir. Psikolojik daışma ve rehberlik hizmetlerinin 
önemli bir bölümünü oluşturan önleyicilik, daha problemler ortaya çıkmadan ortaya çıkabilecek olası problemlerin engellenmesi olarak ifade edilmektedir (Şahin, 2009). Burada sunulan güçlü yönlere yönelik uygulamalar sayesinde öğrencilerin kendi güçlü yönlerinin farkına vararak ve bunları kullanarak aslında daha sorunları oluşmadan bu sorunlarını önleyeceği düşünülmektedir.

Demir ve Murat (2021), okul ortamında öğrencilerin güçlü yönlerinin ölçülmesinin önemine işaret ederek kullanılabilecek ölçme araçlarını derlemiştir. Bu bağlamda, ölçme araçlarının öğrencilerin güçlü yönlerinin farkına varılmasında, desteklenmesinde, baskın güçlü yönlerin belirlenmesinde, hizmetlerin planlanmasında, uygulamaların verimliliğinin değerlendirilmesinde vb. birçok alanda faydası olabileceği belirtilmiştir. Okullarda kullanılabilecek ölçme araçları olarak şunlar sunulmaktadır: Karakter Güçleri ve Erdemli Oluş Gençlik Envanteri [(Geliştirme: Park ve Peterson, 2006; Peterson ve Seligman, 2004), (Uyarlama: Kabakçı, 2013)], Karakter Gelişim İndeksi [(Geliştirme: Liston, 2014), (Uyarlama: Ekşi vd., 2017)], Güçlü Yönler Öz Yeterlik Ölçeği [(Geliştirme: Tsai vd., 2014), (Uyarlama: Dönmezoğulları ve Nazlı, 2019; Sarıçam vd., 2019)].

\section{GÜÇLÜ YÖNLERE YÖNELİK SINIF UYGULAMALARI}

\section{Güçlü Yönler Sınıfı}

Her sınıfın öğrencilerinin güçlü yönlerine ilişkin profilleri ölçme araçlarından ve bu çalışma içerisinde yer alan diğer uygulamalardan yararlanılarak çıkarılabilir. Daha sonrasında tüm sınıf değerlendirerek ilgili sınıfın güçlü yönler profili çıkarılabilir. Böylelikle her sınıfın baskın olduğu güçlü yön belirlenebilir. Öğrencileri teşvik amaçlı sınıfın kapısına ilgili sınıfın adının, güçlü yönün isminin ve onu temsil eden bir fotoğrafın olduğu bir flama asılabilir. Sınıftaki öğrenciler kendilerinin ortaya çıkan güçlü yönüne ilişkin ara koridordaki veya sınıflarındaki panolarına diğer okul öğrencilerinin faydalanabileceği şekilde pano çalışması hazırlayabilir. Ayrıca sınıftaki öğrencilerin ilgili güçlü yönü okul ortamında diğer öğrencileri de kapsayacak şekilde ne gibi etkinlikler yapabilecekleri planlanabilir. Böylelikle sınıf ilgili güçlü yönü temsil eder ve onun keşfedilmesi ve işlevsel şekilde nasıl kullanılabileceği ile ilgili tüm okula örnek oluşturabilecek çalışmalar yapar.

\section{Güçlü Yönler Şahsiyetleri}

Karakter güçleri sınıflamasında yer alan karakter güçlerinin her birini temsil eden şahsiyetler belirlenebilir. Şahsiyetlerin biyografileri öğrenciler tarafından araştırılarak sınıfta veya okul törenlerinde her hafta ilgili gücü temsil eden şahsiyetin biyografi okunabilir. $\mathrm{Bu}$ uygulama sınıf ortamında yapılırsa ilgili güçlü yön üzerine konuşma, ilgili şahsiyetin hangi 
durumlarda güçlü yönünden faydalandığının değerlendirilmesi, öğrencilerin kendini ilgili güçlü yön açısından değerlendirmesi, ilgili güçlü yönü işlevsel kullanabildikleri kendi yaşam olayları, etkinliğe ilişkin kazanımları/düşünceleri/hisleri vb. konular ele alınabilir. Bunun yanında, ilgili güçlü yönü temsil eden şahsiyetin eğer varsa hayat hikâyesini ele alan kitap, belgesel, film sınıf, okul veya ev ortamında öğrencilerin izlenmesi için kullanılabilir. Bununla birlikte, ilgili gücü temsil eden şahsiyetin hayatı ile ilgili bilgiler ve görsellerin yer aldığı sınıf ve okul panosu çalışmaları yapılabilir.

\section{Güçlü Yönler Senaryoları}

Öğrencilere farklı karakter güçlerine uygun senaryolar oluşturulabilir veya hazır senaryolar temin edilebilir. Sınıf ortamında bu senaryoları canlandırması için gönüllü öğrencilere kendi istedikleri roller verilebilir. Öğrencilerin ilgili senaryoları sınıf ortamında canlandırması istenebilir. Canlandırma sonrasında öğrencilerin o rolü neden seçtiği, karakterle ne bağ kurduğu, rolü canlandırırken neler hissettiği vb. paylaşmalar yapmaları sağlanabilir. Öğrencilerin buradaki karakterlerin hangi güçlü yönlerini kullandıklarını, bunları kullanırken neler yaptıklarını, nelere dikkat ettiklerini, günlük hayatımızda bu karakter gücünü hangi durumlarda nasıl kullanabileceğimizi vb. sorularla paylaşım yapmalarını sağlanabilir. Eğer tüm öğrenciler rol almadı ise diğer öğrencilerin de canlandırma sonrası paylaşım sürecinde aktif katılımlarını teşvik edilebilir.

\section{Güçlü Yönler Kariyer Listesi}

Özellikle lise ve ortaokul kademelerinde uygulanabilecek bir uygulamadır. Öğrencilere karakter güçleri tanıtılarak başlanabilir. Bunun ardından her öğrenci kendi karakter güçlerini belirleyebilir. Öğrencilerin düşündükleri meslekleri belirlemeleri ve bunlar hakkında araştırma yapmaları istenebilir. Özellikle mesleğin gerektirdiği kişilik özelliklerinin yer almasına dikkat edilir. Daha sonra her öğrencinin bir tarafa güçlü yönlerini diğer tarafa da mesleğin gerektirdiği kişilik özelliklerini belirtmeleri ve düşündüğü mesleğin kendi güçlü yönleri ile ne kadar uyuştuğunun farkına varması sağlanabilir. $\mathrm{Bu}$ süreç ödevlendirmeler ile belirli günlere yayılabilir. Süreç boyunca öğrencilerin neler yaşadığı, neler hissettiği, meslek ve kendi güçlü yönleri ile ilgili nelerin farkına vardığı vb. durumlar paylaşılabilir.

\section{Güçlü Yönler Kartı}

Özellikle okul öncesi ve ilkokul öğrencilerine yönelik öğrencilerin güçlü yönlerini keşfetmeleri için kullanılabilir. Uygulayıcı tarafından her bir karakter gücünü temsilen bir fotoğraf, bir resim veya bir karikatür vb. olan kartlar sınıf ortamında öğrencilere karakter güçleri tanıtılırken kullanılabilir. Öğrencilerin karakter güçlerini bu şekilde tanıdıktan sonra kendi güçlü yönlerini paylaşmaları ve bulmaları teşvik edilir. Bu aynı anda olabileceği gibi diğer 
bir zamana ödev olarak verilebilir. Bundan sonra, gerektiğinde ailenin de desteği ile öğrencilerin kendi güçlü yönlerini temsil eden resim, fotoğraf, karikatür bulmaları daha da güzel olanı kendilerinin oluşturmaları istenebilir.

\section{Güçlü Yönler Takvimi}

Her sınıfta bir "Güçlü Yönler Takvimi” oluşturulabilir. Bu takvim öğrenciler tarafından uygulayıcının desteği ve teşviki ile hazırlanabilir. Her güne özgü bir tane ilgili güçlü yönle ilişkili bir kısa hikâye, bir şahsiyetin hayatı, bir fotoğraf, bir örnek uygulama vb. seçilerek takvime işlenebilir. Her gün ilgili gündeki yapılanlar tüm sınıf öğrencilerine okunabilir. Böylelikle öğrenciler her gün bir güçlü yöne ilişkin bilgi edinmiş ve uygulama önerisi elde etmiş olur.

\section{Güçlü Yönler Ağacı}

Tüm kademelerde kullanılabileceği gibi okul öncesi ve ilkokul çocuklarında daha etkin kullanılabilir. Tahtaya büyükçe bir ağaç çizilebilir ya da kartonlardan sınıfın uygun bir yerine ya da sınıfın bulunduğu koridora büyükçe bir ağaç oluşturulabilir. Ağacın gövdesine "... sınıfının güçlü yönleri” yazılabilir. Öğrencilere karakter güçleri tanıtıldıktan sonra her öğrencinin kendisinde hangi güçlü yönün olduğunu belirlemesi sağlanabilir. Öğrenci güçlü yönü bulmakta zorluk yaşarsa sınıf arkadaşlarından destek alınabilir. Her öğrenci güçlü yönünü belirledikten sonra güçlü yönünü temsil eden bir meyve sadece kendisi asılabileceği gibi güçlü yönün ismi yazılarak da asılabilir. Böylelikle tüm sınıfın güçlü yönleri belirlenmiş olur.

\section{Güçlü Yönler Filmleri}

Öğrencilerin özellikle ergenlik dönemindeki öğrencilerin filme olan ilgisi güçlü yönlerin ele alınması adına fayda sağlayabilir. Sınıf veya okul bazında her hafta veya belirli aralıklarla bir tane karakter gücü belirlenip ilgili karakter gücü ile ilgili öğrencilerin gelişim dönemi özellikleri ve okul veya sınıfın fiziki şartları göz önünde bulundurularak film izlenebilir. Özellikle bu konuda Filmlerle Pozitif Psikoloji (Niemiec ve Wedding, 2018) kitabından yararlanılabilir. Kitapta, karakter güçlerini ele alan çok sayıda film bulunmaktadır.

\section{Güçlü Yönler Kitaplığı}

Okullarda her sınıfın kendi kitaplığı bulunmaktadır. Yine tüm okul öğrencilerinin faydalandığı okul kütüphanesi de mevcuttur. İster okul kütüphanesi ister sınıf kitaplığının bir bölümü güçlü yönler kitaplığı olarak tasarlanabilir. Buraya her bir karakter gücünün işlendiği kitaplar konularak her hafta veya belirli aralıklarla öğrencilerin belirlenen karakter güçlerine ilişkin okuma yapmaları sağlanabilir. Öğrencilerin okumalardan sonra paylaşım yapmalarına fırsat sağlayacak zaman ayrılmalıdır. 


\section{Güçlü Yönler Metaforu}

Uygulayıcı tarafından sınıf ortamında güçlü yönlerle ilgili bilgi verilerek başlanabilir. Sonrasında ilgili güçlü yönün neye benzetilebileceği üzerinde öğrencilerin düşünülmesi istenebilir. Uygulayıcı tarafından bir örnek verilebilir. Sonrasında öğrencilerden ilgili güçlü yönü bir hayvan, eşya, bitki, şehir, ülke, meslek vb. benzetmesi teşvik edilebilir. Öğrencilerin neden ilgili güçlü yönü seçtiği şeye benzettiği, hangi yönden benzerlik kurduğu vb. sorulabilir. Daha sonra öğrencilerin ilgili güçlü yöne sahip olup/olmama, ilgili güçlü yönü işlevsel olarak kullandıkları örnekler vb. üzerinde konuşulabilir.

\section{Güçlü Yönler Sessiz Sineması}

Sessiz sinema oyunu güçlü yönlerle ilişkilendirilebilir. Öğrencilerin gelişim dönemi özelliklerine uygun bir şekilde tüm sınıf veya sınıftaki belirlenen gruplar arasında oynanabilir. Belirlenen güçlü yönleri temsil edecek genişçe bir film listesi belirlenebilir. Bu filmlerden seçilerek öğrencilerin sessiz sinema oyununda olduğu gibi sözcük kullanmadan filmleri anlatmaları istenebilir. Oyunda kullanılan her film sonrası filmle ilgili öğrencilerin konuşması, filmdeki güçlü yönü ele alması, güçlü yönün nasıl işlevsel kullanıldığına dikkat edilmesi, öğrencilerin düşünce ve duygularını paylaşmalarını teşvik etmesi, kendilerinin ilgili güçlü yöne sahip olup/olmama durumu, ilgili güçlü yönü kendilerinin işlevsel şekilde kullanabildikleri örnek yaşantılar vb. üzerinde durulabilir.

\section{Güçlü Yönler Jengası}

Öğrencilerle karakter güçlerini eğlenerek keşfedebilecekleri bir oyun tasarlanabilir. Sınıf ortamında öğrenciler belirli gruplara ayırabilir. Daha önceden hazırlanan jengalar öğrencilere dağıtılabilir. Jenja yüzlerinde şunların bulunması tavsiye edilir. Bir tarafa karakter gücünün ismi, diğer tarafa öğrencilerin seviyesine uygun kısa bir tanımını, bir tarafa karakter gücünü temsil eden fotoğraf, resim, karikatür vb. bir görsel, diğer tarafına karakter gücünün kullanılabileceği bir durum, bir olay ya da bir sorun yer alabilir. Böylelikle sıra kendisine gelen her öğrencinin kendi çektiği tahtadaki karakter gücünü seslendirmesi ve gruptaki diğer arkadaşları ile paylaşması sağlanabilir. Daha sonra ilgili karakter gücünün kendisinde hangi derecede (yüksek, orta, düşük) olduğunu ifade etmesi sağlanabilir. Bu karakter gücünü kullandığı bir durumu arkadaşları ile paylaşması istenebilir. Gruplar oyunlarını bitirdikten sonra sınıfça oyunda ne yaşadıkları, neler düşündükleri, neler hissettiklerini, nelerin farkına vardıklarını, karakter güçleri anlamında kendilerinde nelerin farkına vardıkları vb. sorularla paylaşım yapmaları teşvik edilebilir. 


\section{Güçlü Yönler Yapbozu}

Özellikle ilkokul ve okul öncesi öğrencilerine yönelik olarak kullanılabilir. Karakter güçlerinin isimlerinin ve onları temsil eden resim, fotoğraf, karikatür vb. olduğu bir yapbozu uygulayıcı olarak siz tasarlayabilirsiniz. Yapbozun parçalarının sayısının, büyüklüğünün, kelimegörsel dengesinin vb. öğrencilerin gelişim özelliklerine göre uyarlanması tavsiye edilir. Yapboz, bireysel veya gruplar halinde öğrencilerin tamamlaması için onlara verilebilir. Öğrencilerin yapbozu tamamlarken etkileşim halinde olmaları, buldukları parçalardaki karakter gücü ve temsili görsel hakkında paylaşımda bulunmaları teşvik edilebilir. Etkinlik tamamlandıktan sonra öğrencilerin yaşantılarına, öğrendiklerine, hislerine vb. ilişkin paylaşımda bulunmaları sağlanabilir.

\section{Güçlü Yönler Bulmacası}

Öğrencilerin gelişim dönemi özelliklerine uygun bir şekilde güçlü yönlerin yer aldığı bulmacalar uygulayıcı tarafından tasarlanabilir. Bu bulmacalarda güçlü yönlere yer verilerek öğrencilerin bunları bulması sağlanabilir. Her bulunan güçlü yönün üzerinde konuşulması değerlidir. İlgili güçlü yönün öğrenci de olup/olmaması, günlük yaşamında işlevsel olarak nerelerde kullanabildiği vb. üzerinde konuşulabilir.

\section{Güçlü Yönler Küpü}

Bir küpün 6 yüzü vardır. Öğrencilere her bir erdem bir yüzeye gelecek şekilde küp ayarlanabilir. Küpün yüzeylerine ilgili erdem ve onu temsilen bir fotoğraf, resim, karikatür vb. yerleștirilir. Tüm sınıf sırasıyla ya da belirli gruplara ayrılarak öğrenciler tarafından küp atılır. Küpün hangi yüzeyi geldi ise o yüzeydeki karakter gücü okunarak arkadaşlarına gösterilir. İlgili erdemin ne anlama geldiği, kendi açısından tanımlaması istenebilir. İlgili erdeme yönelik olarak kendi yaşamında yaptığı bir uygulama arkadaşlarına anlatılabilir.

\section{Güçlü Yönler İsim-Şehiri}

İsim-şehir oyunun güçlü yönlere uyarlanmış halidir. Bir kâğıda güçlü yön ve güçlü yönü temsil eden kişi ismi-şehir-bitki-hayvan-eşya gibi sütunlar daha da arttırılarak ya da uygulamaya göre daha da azaltılarak yazılabilir. Sıradaki öğrenci içinden alfabeyi sayarken bir sonraki öğrenci durdurarak hangi harfte kaldı ise o harfle ilgili güçlü yön ve güçlü yönü temsil eden isimşehir-bitki-hayvan-eşya bulunmaya çalışabilir. İlk bitiren 30'a kadar sayar ve tamamlanabilir. Hiç yazamayan 0 , aynı yazanlar 5 , farklı yazan 10 puan şeklinde alabilir. Böylece oyun istenildiği kadar devam eder. Oyunu oynarken öğrencilerin yazdıkları üzerine paylaşımda bulunmaları sağlanabilir. Neden o kişiyi, şehri, bitkiyi, hayvanı, eşyayı vb. yazdığı, hangi özellikleri ile ilgili güçlü yönü temsil ettiği vb. șeklinde paylaşımlar yapılabilir. 


\section{Güçlü Yönlerimi Kullanıyorum}

Öğrencilerin güçlü yönleri belirledikten sonra her öğrenci için kendisinde bulunan güçlü yönlerini kullanabilmeleri için onlara gün içerisinde güçlü yönlerini kullandıkları olayları kaydetmeleri istenebilir. Öğrencilerin hangi alanda, hangi olayda güçlü yönlerini kullandıklarını paylaşmaları istenebilir. İlgili güçlü yönünü kullanmanın o olayda ya da problemi aşmada nasıl bir katkı sağladığı üzerinde durulabilir. İlgili güçlü yönünü kullanmasının kendisinde neler hissettirdiği üzerinde konuşulabilir. Her gün veya her hafta bu şekilde güçlü yönlerini kullandığı durumları kayıt etmeleri sağlanabilir. Böylelikle öğrenciler, güçlü yönlerinin daha çok farkına varabilecek ve daha işlevsel olarak kullanabilecektir.

\section{Problemlere Karşı Güçlü Yönlerim}

Öncelikle, öğrencilerin güçlü yönlerinin neler olduğu diğer uygulamalarda yer alan yöntemlerle öğretilebilir. Sonra öğrencilere ev ödevi verilebilir. Her öğrencinin kendi güçlü yönlerini yazması istenebilir. Sonra öğrencilerin yazdıkları kağıtları cebinde taşımalarını istenebilir. Daha sonra gün içerisinde karşılaştıkları problem anlarında cebindeki bu kâğıtta yazan güçlü yönlerini aklına getirmeleri istenebilir. Sahip olduğu güçlü yönlerinden hangisini o anda yaşadı̆̆ı problemde nasıl kullanabileceğini düşünmesi istenebilir. Daha sonra ilgili problemde kullanıp kullanmadığını not alması istenebilir. Güçlü yönünü kullanmadığı veya kullandığı problemlerinde nelerin farklı olduğunu not almalarını istenebilir. Öğrencinin sınıf ortamında bu çalışmaları yaparken yaşadıklarını paylaşmasını, yorumlamasını, hissettiklerini, ilgili karakter gücünü kullandı̆̆ı durumları paylaşması teşvik edilebilir.

\section{Güçlü Yönler Listem}

Her öğrenc için öğrencilerin güçlü yönlerinin olduğu bir liste oluşturmaları sağlanabilir. $\mathrm{Bu}$ listeyi öğrenciler yanında taşıyabilir. Her hafta en az bir güçlü özelliğini bir durumda kullanması istenebilir. Kendilerinin karşılaştıkları bir durum olmasa bile öğrencilerin kendi oluşturabilecekleri durumlarda kullanabilecekleri belirtilebilir. Her hafta ilgili güçlü yönünü kullandığı durumları not etmelerini istenebilir. Bu uygulamanın kendilerine katkıları ve uygulama sırası ve sonrası hislerini paylaşmaları istenebilir. Böylelikle öğrenciler, kendi güçlü yönlerinin farkına varıp daha işlevsel șekilde kullanabilecektir. Güçlü yönlerinin hayatlarına katkısını daha somut şekilde görebilecektir.

\section{Güçlü Yönler Günlüğüm}

Öncelikle, öğrencilerin güçlü yönlerini belirlemesini sağlanabilir. İlgili güçlü yönlerini gün içerisinde kullandığı durumların farkına varmaları teşvik edilebilir. Her günün sonunda hangi güçlü yönünü bugün kullandığını, kullandığı bu güçlü yönü hangi durumda kullandığını ve kendisine katkısının neler olduğunu yazmalarını istenebilir. Ara ara günlüklerini kendilerinin 
okumaları, güçlü yönlerini nasıl kullandıklarının farkına varmaları sağlanabilir. Gönüllü öğrencilerin günlüklerinden sınıf içi paylaşım yapmaları sağlanarak diğer öğrencilerin de farklı güçlü yönleri farklı durumlarda nasıl kullanabileceğine ilişkin onlara fikir verilebilir.

\section{Güçlü Yönler Aktivitelerim}

Öğrencilerin güçlü yönlerinin neler olduğu çeşitli yöntemlerle öğretilebilir. Daha sonra öğrencilere ev ödevi verilebilir. Her öğrencinin kendi güçlü yönünü yazması istenebilir. Daha sonra ilgili güçlü yönünü kullanabileceği her hafta bir aktivite planlaması ve ilgili güçlü özelliğinin karşısına not alması istenebilir. Öğrencilerin belirlediği aktiviteleri yapması istenebilir. Öğrencinin sınıf ortamında bu çalışmaları yaparken yaşadıklarını paylaşması teşvik edilebilir

\section{Arkadașlarımın Gözünden Güçlü Yönlerim}

Öncelikle, öğrencilerin güçlü yönlerinin neler olduğu diğer uygulamalarda yer alan yöntemlerle öğretilebilir. Öğrencilerin karakter güçlerini öğrendiğinden emin olduktan sonra her öğrencinin kendi sıra arkadaşının karakter güçlerini yazması istenebilir. Diğer bir öneri de ki daha zengin bir içerik sunabilir. Tüm sınıfın sizin belirlediğiniz bir öğrenci ile ilgili güçlü yönlerini yazmasını istenebilir. Yazan öğrencilerin kendilerini daha rahat ifade edebilmeleri için isim belirtmelerine gerek görülmeyebilir. Tüm kağıtları bir kişi toplayıp ya da bir kavanozda toplanıp ilgili öğrenciye teslim edilebilir. Bir derste tüm öğrenciler için yapma imkânı olmazsa her derste birkaç öğrenci için yaplarak belli bir sürede tüm öğrenciler tamamlanabilir. Öğrencinin yazılanları okumasını, yorumlamasını, hissettiklerini, ilgili karakter gücünü kullandığı durumları paylaşması teşvik edilebilir. Böylelikle tüm öğrenciler arkadaşlarının gözünden kendi karakter güçleri üzerinde düşünmeye, karakter güçlerini keşfetmeye başlayabilecektir.

\section{Ailemin Gözünden Güçlü Yönlerim}

“Arkadaşlarımın Gözünden Güçlü Yönlerim” uygulamasının aileye uyarlanmış halidir. Şöyle ki öncelikle, öğrencilerin güçlü yönlerinin neler olduğu diğer uygulamalarda yer alan yöntemlerle öğretilebilir. Daha sonra ev ödevi şeklinde tüm öğrencilerin kendi ailesindeki kişilere karakter güçlerini anlatması ve kendisindeki karakter güçlerinin ne olduğu üzerinde aile sohbeti etmesi istenebilir. Öğrencinin sınıf ortamında ailesinin kendisi için söylediklerini paylaşmasını, yorumlamasını, hissettiklerini, ilgili karakter gücünü kullandı̆̆ı durumları paylaşması teşvik edilebilir. Böylelikle tüm öğrenciler ailesinin gözünden kendi karakter güçleri üzerinde düşünmeye, karakter güçlerini keşfetmeye başlayabilecektir. 


\section{SONUÇ VE ÖNERÍLER}

Bireyin hem zayıf hem de güçlü yönleri bulunmasına rağmen psikoloji tarihi içerisinde uzunca bir dönemdir yoğun olarak bireyin sadece zayıf taraflarına odaklanılmıştır. Bu durumu eleştiren pozitif psikoloji, bireyin var olan güçlerinin önemine değinmiş ve bireyin güçlü yönlerini önemli çalışma konusu haline getirmiştir. Pozitif psikolojinin çalışma alanlarından birisi de eğitim kurumlarıdır. Bu bağlamda, öğrencilerin vakitlerinin çoğunu geçirdiği ve birçok anlamda yeni öğrenmeler gerçekleștiği kurumlar olan okullarda öğrencilerin güçlü yönlerinin keşfedilmesi ve desteklenmesi önemli görülmektedir. Bu şekilde öğrencilerin güçlü yönlerinin geliștirilmesi onların gerek okul yaşamında gerekse yaşamlarının diğer alanlarında problemleri ile baş etmesinde, olumlu davranışlar sergilemesinde, daha mutlu ve doyumlu bir yaşam sürdürmesinde katkı sunabilecektir. Elbette ki güçlü yönlerin desteklenmesi sadece öğrencilerin bahsedilen sosyal-duygusal özelliklerine katkı sunmakla kalmayacak bu özelliklerini kullanan öğrencilerin aynı zamanda akademik ve kariyer gelişimlerine katkı sağlayacaktır.

Okulda öğrencilerin güçlü yönlerinin desteklenmesi birçok yol ile sağlanabilir. İlk olarak, okul geneli yapılabilecek güçlü yönlere yönelik uygulamalar tüm okul öğrencilerinin dikkatini çekecek ve oluşturulan olumlu okul ikliminden tüm öğrenciler etkilenebilecektir. Bu kapsamda, okul personelinin hep birlikte genelde pozitif psikoloji özelde güçlü yönlere yönelik okul geneli uygulamaların önemini kavraması, getirilerine inanması ve yapılan uygulamalar içerisinde aktif olarak yer alması okul atmosferini olumlu anlamda etkileyecektir. Bir diğer uygulama olarak sınıf içi yapılabilecek uygulamalardan yararlanılabilir. Bu çalışmada da öğrencilerin güçlü yönlerini keşfetmesine ve işlevsel olarak kullanmasına katkı sağlayabilecek uygulama önerileri sunulmuştur. Çalışma boyunca önerilen uygulamalar, sınıflarda başta psikolojik danışmanlar olmak üzere sınıf rehber öğretmenleri, branş öğretmenleri ve sınıf öğretmenleri tarafından rahatlıkla uygulanabilir. Bu uygulamalar yapılırken çalışmanın içerisinde yer alan unsurların dikkate alınması fayda sağlayacaktır. Bir diğer uygulama olarak da psikolojik danışmanlar gerek bireysel gerek grupla yapılan danışma ve rehberlik hizmetlerinde yine öğrencilerin güçlü yönlerini geliştirmeyi hedefleyecek çalışmalar yapabilir. 


\section{KAYNAKÇA}

Boniwell, I. (2012). Positive psychology in a nutshell: The science of happiness. McGraw-Hill Open University Press.

Buckingham, M., \& Clifton, D. O. (2001). Now, discover your strengths. Simon \& Schuster.

Demir, R., \& Murat, M. (2021). Okulda güçlü yönlerin keşfedilmesi ve desteklenmesi. İçinde G. Arslan \& M. Ylldırım (Ed.), Okulda Pozitif Psikoloji Kuramdan Uygulamaya. Pegem Akademi.

Demir, R., \& Türk, F. (2020). Pozitif psikoloji: Tarihçe, temel kavramlar, terapötik süreç, eleștiriler ve katkılar. Humanistic Perspective, 2(2), 108-125.

Dönmezoğullari, C., \& Nazli, S. (2019). Güçlü yönler öz yeterlilik ölçeği Türkçe formunun geçerlik ve güvenirliği. Anemon Muş Alparslan Üniversitesi Sosyal Bilimler Dergisi, 7(4), 257-265.

Ekşi, H., Demirci, İ., Kaya, C.., \& Ekşi, F. (2017). Karakter gelişim indeksinin Türk ergenlerdeki psikometrik özellikleri. Ege Eğitim Dergisi, 18(2), 476-500.

Eryılmaz, A. (2013). Pozitif psikolojinin psikolojik danışmanlık ve rehberlik alanında gelişimsel ve önleyici hizmetler bağlamında kullanılması. The Journal of Happiness \& Well-Being, $1(1), 1-22$.

Hefferon, K., \& Boniwell, I. (2014). Pozitif psikoloji: Kuram, araştırma ve uygulamalar. T. Doğan (Çev. Ed.). Nobel Akademik Yayıncılık.

Hokanson, B., \& Karlson, R. W. (2013). Borderlands: Developing character strengths for a knowmadic world. On the Horizon, 21(2), 107-113.

Kabakçı, Ö. F. (2013). Karakter güçleri açısından pozitif gençlik gelişiminin incelenmesi. [Doktora tezi]. Hacettepe Üniversitesi.

Liston, M. A. (2014). Conceptualizing and validating the character virtues index (CVI). University of Missouri. ProQuest Dissertations and Theses.

Milli Eğitim Bakanlığı, (2020). T. C. Milli Eğitim Bakanlığı sınıf rehberlik programı.

Molony, T., \& Henwood, M. (2010). Signature strengths in positive psychology. Communiqué, 38(8), 15-16.

Niemiec, R. M., \& Wedding, D. (2018). Filmlerle pozitif psikoloji: Karakter güçlerini geliştirmek için filmlerden yararlanma. G. Kafa (Çev.). Kaknüs Yayınları.

Park, N., \& Peterson, C. (2006). Moral competence and character strengths among adolescents: The development and validation of the Values in Action Inventory of Strengths for Youth. Journal of Adolescence, 29(6), 891-909.

Peterson, C., \& Park, N. (2004). Classification and measurement of character strengths: Implications for practice. In P. A. Linley, \& S. Joseph (Eds.), Positive Psychology in Practice. John Wiley \& Sons, Inc..

Peterson, C., \& Seligman, M. E. P. (2004). Character strengths and virtues: $A$ handbook and classification. American Psychological Association \& Oxford University Press.

Popov, L. K. (2000). The virtues project educator's guide: Simple ways to create a culture of character. Jalmar Press.

Rath, T. (2007). StrengthsFinder 2.0. Gallup Press.

Şahin, C. (2009). Eğitim sürecinde öğrenci kişilik hizmetleri ve rehberlik. İçinde M. Güven (Ed.). Psikolojik Danışma ve Rehberlik. Anı Yayıncılık.

Sarıçam, H., Mert, A., \& Çelik, İ. (2019). Güçlü yönler öz-yeterlik ölçeğinin Türkçe versiyonunun psikometrik özellikleri. OPUS Uluslararası Toplum Araștırmaları Dergisi, 14(20), 288-313.

Seligman, M. E. P. (2002). Positive psychology, positive prevention and positive therapy. In C. R. Snyder, \& S. J. Lopez (Eds.), Handbook of Positive Psychology. Oxford University Press. 
Tsai, C. L., Chaichanasakul, A., Zhao, R., Flores, L. Y., \& Lopez, S. J. (2014). Development and validation of the strengths self-efficacy scale (SSES). Journal of Career Assessment, 22(2), 221-232.

Yeşilyaprak, B. (2010). Eğitimde rehberlik hizmetleri. Nobel Yayın Dağıtım. 


\section{EXTENDED ABSTRACT}

When the history of psychology is examined, it is seen that psychology aims to eliminate or reduce the problems of individuals or groups. Besides, there are also approaches that focus on the positive aspects of the individual or groups. However, for a long time, psychology was largely concerned with deficiencies, problems, and symptomspractices. One of the most rooted criticisms of this situation has come with the positive psychology approach. Positive psychology stated that individuals and groups have strengths as well as weaknesses. In this context, positive psychology focuses on the strengths/character strengths of the individual. Discovering and developing strengths has been an important field of study for positive psychology (Demir ve Türk, 2020; Hefferon ve Boniwell, 2014).

There are many studies on the positive psychology approach today. One of these fields is education. Positive psychology approach and concepts are studied in educational institutions and it is aimed to make these institutions better. Examining strengths in school and classroom environments can bring great benefits for educational institutions and individuals in educational institutions. Especially teachers and psychological counselors, who are in constant interaction with students at school, can help students discover their strengths and use them functionally (Demir ve Murat, 2021). If the mental health professionals at the school help students discover and develop their character strengths, can make the school climate positive by contributing to their academic development, self-efficacy and happiness (Molony ve Henwood, 2010). When the Ministry of National Education Classroom Guidance Program (2020) is examined, it is seen that positive psychology is used and character strengths are included. In this context, 6 virtues and 24 character strengths, which are expressed as virtues and character strengths in the classification of Seligman and Peterson (2004), are mentioned. It is seen that the Ministry of National Education gives importance to the discovery and development of the strengths of the students in the classroom guidance practices to be presented to the students.

Demir and Murat (2021) suggest studies to discover and support strengths in the school environment. These practices are expressed as Strengths Newspaper and Journal, Strengths Clubs, Strengths Competitions, Strengths Certificate, Strengths Box, Strengths Exhibition, Strengths Corner. The authors stated the things to be considered during the mentioned practices. These are the characteristics of the developmental period of the students, the needs of the school and the students, the school's facilities, and the support of the school staff. They stated that existing practices can be adapted according to these criteria and new ones can be developed. In this study, practices that can contribute to the support of strengths in the classroom are presented. These practices are Strengths Class, Strengths Personas, Strengths Scenarios, Strengths Career List, Strengths Card, Strengths Calendar, Strengths Tree, Strengths 
Movies, Strengths Library, Strengths Metaphor, Strengths Charades, Strengths Jenga, Strengths Jigsaw, Strengths Puzzle, Strengths Cube, Strengths Name-City, I Use My Strengths, My Strengths Against Problems, My Strengths List, My Strengths Diary, My Strengths Activities, My Strengths in The Eyes of My Friends, My Strengths in The Eyes of My Family.

Although the individual has both weaknesses and strengths, for a long time in the history of psychology, only the weak sides of the individual have been intensely focused. Positive psychology criticized this situation, emphasized the importance of the individual's existing strengths and made the individual's strengths an important subject of study. One of the study fields of positive psychology is educational institutions. In this context, it is important to discover and support the strengths of students in schools. In this way, the development of students' strengths will benefit them both in school life and in other areas of life. Students will be able to cope with their problems, exhibit positive behaviors, and have a happier life. Supporting strengths will not only contribute to the social-emotional characteristics of students, but will also contribute to their academic and career development.

Supporting students' strengths at school can be achieved in many ways. First of all, practices for strengths at school will attract the attention of all students and all students will be affected by the positive school climate created. In this context, the school staff's understanding of the importance of positive psychology in general and strengths in particular, their belief that it will provide benefits and their active participation in practices will positively affect the school atmosphere. As another option, in-class practices can be used. In this study, application suggestions are presented for students to discover their strengths and use them functionally. The practices suggested throughout the study can be easily applied by counselors, classroom guidance teachers, branch teachers, and classroom teachers. It will be beneficial to consider the elements included in the study while making these practices. As another option, counselors can apply studies that will support the strengths of students in counseling and guidance services, both individually and in groups. 